\title{
Propulsion Subsystem On Low Cost Electric Vehicles Using Common Large Scale Industrial Equipment
}

\author{
Claudinilson A. Luczkiewicz ${ }^{1}$ César D. Paredes Crovato ${ }^{2}$ \\ Department of Electrical Engineering \\ Universidade Vale do Rio dos Sinos \\ Campus of São Leopoldo - Rio Grande do Sul, (Brazil) \\ e-mail: ${ }^{1}$ claudiocalz@hotmail.com, ${ }^{2}$ ccrovato@unisinos.br
}

\begin{abstract}
The aim for this paper is to analyze parameters for the propulsion system of vehicles in urban operating conditions through the longitudinal dynamics, in order to map out devices and commonly used large scale industrial equipment, which could be used in these vehicles, maintaining compatible cost and performance characteristics. It is sought to shorten time-tomarket, which is typically high when developing proprietary solutions, and also to reduce typically high costs when using specific devices for electric cars, which are less disseminated than the industrial devices proposed. Industrial equipment such as induction motors and inverter drives using conventional power sources were analyzed through the study of catalog listing information and axiomatic methods. Furthermore, it is demonstrated that the power supply, through conventional acidlead batteries would be the main limiting factor for performance, stressing the need for other more effective and lighter sources. It also demonstrates that, for the national context, the two-power train rear wheel drive configuration with automotive acidic lead source presents the best feature to be implemented in the traction system of an urban electric vehicle.
\end{abstract}

Key words. Electric Propulsion, Electric Vehicle, Urban Vehicle, Vehicle Dynamics

\section{Introduction}

One of the main factors attributed to air quality and environmental health is the need to reduce carbon dioxide $(\mathrm{CO} 2)$ and other pollutants from internal combustion engines (ICE) of vehicles. Therefore, the automobile manufacturers were obliged to adapt the ICE propulsion system to the current national and international regulations. Another option was adopting alternative systems for the propulsion system, such as electrical power, in order to reduce the emission of pollutant gases. The development of the mobility with small urban electric vehicles (EVs), buses and utility vehicles could be the right path for the development of electric traction systems in the country. This research, thus, seeks to evaluate the longitudinal dynamics of vehicles aiming to provide an alternative electric traction system for a vehicle using large scale industrial equipment, which could be able to provide torque, speed and power required for an EV model for urban centers use. The propulsion motor connected directly to the wheels have been evaluated in its torque, power and speed characteristics, which have been required to overcome the resistance forces that oppose longitudinal vehicular dynamics, as well urban topographies.

\section{Electric Vehicles}

The automobile has had the function of transporting people and cargo, providing performance, providing drivability and comfort for its occupants, becoming one of the most popular means of transport in the world. The EVs are composed of three main subsystems: propulsion subsystem, energy subsystem and auxiliary subsystems. They use an electric engine for the traction system with wheels and chemical batteries, fuel cells or ultracapacitors as power supply, presenting advantages such as high efficiency and no greenhouse gas emissions. [1]-[2]

\section{A. Vehicles Dynamics}

The SAE J670 technical standard lists a number of movements that may be applied to a vehicle. Regarding the center of gravity, they are defined into longitudinal, lateral and vertical movements for the study of the performance on traction and on braking of a vehicle. The performance reference for acceleration and deceleration characteristics is related to longitudinal dynamics. [3]

The system which provides motion to the vehicle, called powertrain set, includes components such as: engine for propulsion, transmission system, axles, differential set and wheels. The propulsion sources may be classified into conventional, hybrid or alternative.

The powertrain system to be implemented in the vehicle is characterized by the vehicle's model and the traction system connected to the wheels, having effects on the type of the vehicle's application, such as economy, safety and space availability. Therefore, the traction is able to work on the front wheels (FWD - Front-Wheel Drive), rear wheels (RWD - Rear-Wheel Drive) or even on all wheels (AWD - All-Wheel Drive). [4]

The equation to determine the dynamic characteristics of the vehicle is defined on Chart 1. [5] 


\section{B. Electronic Power Converter}

Also known as inverter drive or AC drive, its function is to control the rotation and torque of an electric motor. The inverter, by supplying a power source with a defined frequency, provides an adjustable charge, being able to control the voltage, the electric current and the frequency. The operating characteristics are defined by the power input in the rectifier, filter and inverter, and by the power output to the charge identified in the block diagram, as shown in Figure 2. [6]

At the full-wave rectifier, the AC voltage from the threephase input network are converted into rectified voltage when passing through the diodes. This rectified voltage is turned into a DC voltage after passing through the filter block, also called "DC link".

On some models, the DC link may be accessed through its terminals, after the filter. So, it's possible to make use of a DC source, or even a battery with the help of these inverters, and then the rectifying block can be neglected. This way, it enables the use of general purpose industry inverters in EVs.

On inverter drives for commercial purposes, the power and working voltage information are taken into account. Nevertheless, the characteristics of nominal power, driving system, acceleration and deceleration time, control system and maximum and minimum speed are determining factors for choosing an AC drive. [7]

A pulse generator (encoder) must be attached to the vector control in systems which require torque and speed control, in order to gain better dynamic functions of the electric motors in high frequency, because it is capable of controlling the components of torque and speed from the electric motor.

The equation to determine the characteristics of the inverter drive is defined on Chart 2.

\section{The Electric Motor}

The nominal power rating of the electric motor is defined 'by the torque demanded by the load and the rotation imposed on the load. In normal motoring mode, when the electric motor is directly attached to the load, it is considered that the torque demanded by the load is similar to the nominal motor torque. [8]

The acceleration time in electric motors can be defined by the time the motor might take to leave standby condition until it reaches a nominal speed, being attached to a certain load which defines the specific performance characteristics of each motor according to the number of poles, frequency of operation and slip. The acceleration time can be demonstrated by the average of torque, which can be seen in electric motor manufacturers technical catalogs. Nonetheless, the moment of inertia of the motor combined with the moment of inertia of the load present key characteristics for application on the motor, because both have an effect on the time of acceleration of the motor by presenting a resistance on the rotation movement. [13]

The equation to determine the characteristics of the electric motor is defined on Chart 3. [9]-[10]-[11]-[12]

\section{The Power Supply Source}

On BEVs, the electric power is sourced from a set of batteries that can be recharged at a power grid or at an external auxiliary source to the vehicle. The secondary rechargeable cell battery presents active materials such as lead $(\mathrm{Pb})$ for the negative plates, and lead oxide $(\mathrm{PbO} 2)$ for positive plates submerged into sulfuric acid (H2SO4) as electrolyte. It also has had a container which provides the vehicle a nominal voltage of 12 volts $(12 \mathrm{~V})$. [13] Lead-acid batteries are composed by cells which provide a $2.1 \mathrm{~V}$ nominal voltage and a $1.8 \mathrm{~V}$ minimum safety voltage - to avoid sulfation - each, referring to the temperature of $25^{\circ} \mathrm{C}$. So, the lead- acid batteries require 6 cells in series in order to obtain a $12 \mathrm{~V}$ nominal voltage. [14]

The rated capacity of the battery is given by the discharge rates of power consumption in hours, whose consumption is represented in ampere-hours (Ah). Also, the discharge rate specifications are given at 5, 10 and 20 hours in leadacid batteries, which is equivalent to discharge rates of $0.2,0.1$ and 0.05 of declared capacity. [15]

The equation to determine the characteristics of the power supply source is defined on Chart 4.

\section{The Axiomatic Method for Projects}

The axiomatic method for projects is characterized by axioms which demonstrate empirical basis supported by premises, which are considered to be evident and true, so that they cannot be inferred.

This methodology is established by a matrix systematic analysis of the clients' needs, so as to turn them into functional requirements, in order to fulfill them in the simplest possible way. On the axiomatic approach, four concepts must be applied: domain, hierarchy, zigzag and axioms of the project. [16]. They define the activities and the rules that must be followed during the project.

The concept of domain is related to the approach taken throughout the project process, aiming the customers' needs and demands, in order to develop the project accordingly. The functional domain represents the specific actions to be taken during the project to meet the clients' needs. The physical domain defines the parameter of the project so as to meet the functional domains. The process domain represents the variables of the process that meet the needs of the physical domain. The domains which belong to the project are constant; however, the elements which belong to each domain may be modified. There is an interdependence between the matrix mapping of the project and the axiomatic approach. This interdependence occurs by the change of the processes between the domains. [17]

The change occurs in each pair of adjacent domains associated with each element in the project domains, from the left to the right. Thus, the left domain represents the need and the right domain the solution. The project matrix is the resulting vector of each parameter which meets the functional requirements of the project, and each element held in the matrix represents the change of a functional requirement regarding to the parameter of the project defined in the equation in Chart 5 . In the analysis of the Independence Axiom, there might be three matrix models 
for the project solution, which may be uncoupled, semicoupled or coupled. [18]

\begin{tabular}{|c|c|c|c|c|c|}
\hline Description & Symbol & Characteristic & Id. Equation & Reference Equation & Unit \\
\hline Tractive Power & $P_{t}$ & Tractive effort required & 1.1 & $P_{t}=\sum F x \cdot V$ & {$[k W]$} \\
\hline $\begin{array}{l}\text { Rolling } \\
\text { Resistance }\end{array}$ & $F R_{r}$ & $\begin{array}{l}\text { Rolling resistance force with zero slope, } \\
\text { coefficient of rolling friction }(f r) \text { based on } \\
\text { asphalt paving. }\end{array}$ & 1.2 & $F R_{r}=f r \cdot m \cdot g \cdot \cos (\alpha)$ & {$[N]$} \\
\hline $\begin{array}{l}\text { Runway Slope } \\
\text { Resistance }\end{array}$ & $F g$ & $\begin{array}{l}\text { Defined to overcome slope drag at angles of less } \\
\text { than } 18 \% .{ }^{\circ}\end{array}$ & 1.3 & $F g=m \cdot g \cdot \operatorname{sen}(\alpha)$ & {$[N]$} \\
\hline $\begin{array}{l}\text { Aerodynamic } \\
\text { Drag }\end{array}$ & $F w$ & $\begin{array}{l}\text { Defined by the desired maximum speed and the } \\
\text { aerodynamic characteristics of the vehicle. }\end{array}$ & 1.4 & $F w=\frac{1}{2} \cdot \rho_{a} \cdot C d \cdot A f(V-V v)^{2}$ & {$[N]$} \\
\hline $\begin{array}{c}\text { Inertial Force } \\
\text { on Rotating } \\
\text { Parts }\end{array}$ & Fwa & The rotating parts inertia & 1.5 & $F w a=m^{\prime}{ }_{v} \frac{d V(t)}{d t}$ & {$[N]$} \\
\hline $\begin{array}{l}\text { Resistance } \\
\text { force to } \\
\text { Acceleration }\end{array}$ & $\mathrm{Fa}$ & $\begin{array}{l}\text { Required power to move the vehicle's mass to a } \\
\text { constant speed variation over a period of time }\end{array}$ & 1.6 & $F a=m \frac{d V(t)}{d t}$ & {$[N]$} \\
\hline Motor torque & $T_{m} / C_{n}$ & Motor tractive torque & 1.7 & $T m=\frac{1}{\eta_{t} \cdot i_{g}} \cdot \sum F x \cdot r d$ & {$[N . m]$} \\
\hline Rotation & $n_{N}$ & Drive shaft maximum rotation & 1.8 & $n_{N}=i_{g} \cdot \frac{V}{r d \cdot(2 \pi / 60)}$ & {$[\mathrm{rpm}]$} \\
\hline
\end{tabular}

\begin{tabular}{|c|c|l|c|c|c|}
\hline Chart 2. The equation to determine the characteristics of the AC drive \\
\hline Description & Symbol & \multicolumn{1}{|c|}{ Characteristic } & Id. Equation & Reference Equation & Unit \\
\hline Power & $P_{t}$ & Dependent on the nominal power of the motor & 1.1 & $P_{t}=\sum F x \cdot V$ & {$[\mathrm{~kW}]$} \\
\hline Current & $I_{N}$ & Rated current consumption & $2.1^{2}$ & $I_{N}=\frac{P_{t}}{\sqrt{3} \cdot V_{F} \cdot F P \cdot \eta}$ & {$[A]$} \\
\hline $\begin{array}{c}\text { Output } \\
\text { Rotation }\end{array}$ & $n_{s}$ & $\begin{array}{l}\text { Dependent on the frequency to control the engine } \\
\text { speed }\end{array}$ & 2.2 & $n_{s}=\frac{120 \cdot f_{1} \cdot(1-s)}{p}$ & {$[\mathrm{~Hz}]$} \\
\hline Control & - & Vector & - & encoder - Method PWM sinusoidal \\
\hline
\end{tabular}

\begin{tabular}{|c|c|c|c|c|c|}
\hline Description & Symbol & Characteristic & $\begin{array}{c}\text { Id. } \\
\text { Equation }\end{array}$ & Reference Equation & Unit \\
\hline Average torque & $C_{\text {mméd }}$ & $\begin{array}{l}\text { Average mechanical torque typical of the motor } \\
\text { shaft }\end{array}$ & 3.1 & $C_{m m e ́ d}=0,45 \cdot\left(\frac{C_{P}}{C_{n}}+\frac{C_{\text {máx }}}{C_{n}}\right) \cdot C_{n} \cdot g$ & {$[N . m]$} \\
\hline Load torque & $C_{\text {rméd }}$ & Average torque required by the load & 3.2 & $C_{r m e d}=F x \cdot r d \cdot i_{g}$ & {$[N . m]$} \\
\hline $\begin{array}{l}\text { Moment of } \\
\text { inertia }\end{array}$ & $J_{t}$ & Total Inertia & 3.3 & $J t=J_{l}+J_{m}$ & $\mathrm{kgm}^{2}$ \\
\hline $\begin{array}{l}\text { Time of } \\
\text { Acceleration }\end{array}$ & $T_{a}$ & $\begin{array}{l}\text { Time of acceleration of the electric motor to } \\
\text { reach maximum torque speed }\end{array}$ & 3.4 & $t_{a}=2 \cdot \pi \cdot n_{N}\left(\frac{J_{t}}{C_{\text {mméd }}-C_{\text {rméd }}}\right)$ & {$[s]$} \\
\hline $\begin{array}{l}\text { Time of locked } \\
\text { rotor }\end{array}$ & $\operatorname{Tr} b$ & $\begin{array}{l}\text { Time of temperature limit of the motor winding } \\
\text { through electrical current at starting }\end{array}$ & 3.5 & $t_{a} \leq 0,8 \cdot \operatorname{Tr} b$ & {$[s]$} \\
\hline
\end{tabular}

Chart 4. The equation to determine the characteristics of the power supply source

\begin{tabular}{|c|c|l|c|c|c|}
\hline Description & Symbol & \multicolumn{1}{|c|}{ Characteristic } & $\begin{array}{c}\text { Id. } \\
\text { Equation }\end{array}$ & Reference Equation & Unit \\
\hline Peak voltage & $V_{p i c o}$ & Peak voltage of Power supply & 4.1 & $V_{\text {pico }}=\sqrt{2} \cdot V_{F}$ & {$[V]$} \\
\hline Cell number & $N_{C}$ & $\begin{array}{l}\text { Necessary elements for the power supply, with } \\
\text { variation from -15\% to +10\% of nominal voltage }\end{array}$ & $4.1^{3}$ & $N_{C}=\frac{C_{T}}{M_{V}}$ & Un. \\
\hline
\end{tabular}

\footnotetext{
${ }^{1}$ Runway Slope Resistance presents different characteristics according to slope variations that the topography might present. According to the characteristics of the vehicle dynamics, a resistance force on a minimum inclination to a plane of inclination, a resistance force at a slope of topography up to $18 \%$ is proportional to the angle of inclination and a desired final speed.

${ }^{2}$ Considering average $\quad F P$ of three-phase electric motors over $0,80 \eta$ and over $90 \%$.

${ }^{3}$ The minimal voltage for each cell on lead-acid battery is $(456,79 / 254) 1.80 \mathrm{~V}$, charged $(591,14 / 254) 2,32 \mathrm{~V}$ and nominal voltage $(537 / 254) 2,10 \mathrm{~V}$.
} 


\begin{tabular}{|c|c|l|c|c|c|}
\hline Description & Symbol & \multicolumn{1}{|c|}{ Characteristic } & $\begin{array}{c}\text { Id. } \\
\text { Equation }\end{array}$ & Reference Equation & Unit \\
\hline Rated Capacity & $C$ & $\begin{array}{l}\text { Given by the consumption discharge rate of } \\
\text { electrical power over time in hours }\end{array}$ & $4.2^{4}$ & $\int_{0}^{t} I_{c} d t$ & {$[A h]$} \\
\hline Strings volume & $N_{\text {string }}$ & $\begin{array}{l}\text { Required volume of cells connected in parallel to } \\
\text { meet the rated capacity specifications. }\end{array}$ & 4.3 & $N_{(\text {string })}=\frac{I_{c}}{I_{N}}$ & Un. \\
\hline String current & string & Average current consumption & 4.4 & String $=\frac{I_{c}}{N_{(\text {string })}}$ & {$[A]$} \\
\hline Energy & $E_{F}$ & Energy Rated capacity & 4.5 & $E_{F}=V_{\text {pico }} \cdot I_{N}$ & {$[W h]$} \\
\hline
\end{tabular}

Chart 5. The equation to determine the interactions in axiomatic method

\begin{tabular}{|c|c|l|c|c|c|}
\hline Description & Symbol & \multicolumn{1}{|c|}{ Characteristic } & Id. Equation & Reference Equation & Unit \\
\hline $\begin{array}{l}\text { Vector of } \\
\text { functional } \\
\text { requirements }\end{array}$ & $\{F R\}$ & $\begin{array}{l}\text { New interactions in order to better define } \\
\text { solutions for the project }\end{array}$ & 5.1 & $A_{i j}=\frac{\partial F R_{i}}{\partial D P_{j}}$ & - \\
\hline $\begin{array}{c}\text { Interaction } \\
\text { Matrix }\end{array}$ & $A_{i j}$ & $\begin{array}{l}\text { Matrix of interactions, where each element held } \\
\text { in matrix A represents a functional requirement } \\
\text { alterations because of the project parameter }\end{array}$ & 5.2 & $I=\log _{2}\left(\frac{1}{p_{L}}\right)$ & - \\
\hline $\begin{array}{c}\text { Axiom of } \\
\text { information }\end{array}$ & $I$ & $\begin{array}{l}\text { Determine the probability of a project parameter } \\
\text { satisfying an element of the functional } \\
\text { requirement }\end{array}$ & 5.3 & - \\
\hline
\end{tabular}

\section{Results}

The parameters for the analysis of the propulsion of the vehicle consist into presenting popular characteristics for two occupants, offering a minimum condition of load transport. The nominal power, torque and speed are checked for dimensioning the propulsion system through the dynamic characteristics specifications of the vehicle Therefore, the minimum parameters of the common large scale industrial equipment are set for the project. The parameters for the vehicle are identified in Chart 6 .

\begin{tabular}{|c|c|c|}
\hline Parameter & Symbol & Values \\
\hline $\begin{array}{l}\text { Coefficient of Rolling } \\
\text { Resistance }\end{array}$ & $f r$ & $\begin{array}{c}0.015 \\
\text { (dimensionless) }\end{array}$ \\
\hline Mass of the Vehicle & $m$ & $800 \mathrm{Kg}$ \\
\hline Load Capacity & $m$ & $280 \mathrm{Kg}$ \\
\hline $\begin{array}{l}\text { Gravitational } \\
\text { Acceleration }\end{array}$ & $g$ & $9.81 \mathrm{~m} / \mathrm{s}^{2}$ \\
\hline Slope Angle & $\alpha$ & $10^{\circ}$ \\
\hline Specific Air Mass & $\rho a$ & $1.25 \mathrm{Kg} / \mathrm{m}^{3}$ \\
\hline Aerodynamic Drag & $C d$ & $\begin{array}{c}0,35 \\
\text { (dimensionless) }\end{array}$ \\
\hline $\begin{array}{l}\text { Frontal Area of the } \\
\text { Vehicle }\end{array}$ & $A f$ & $2.26 \mathrm{~m}^{2}$ \\
\hline $\begin{array}{l}\text { Maximum Speed of the } \\
\text { Vehicle }\end{array}$ & $V$ & $80 \mathrm{Km} / \mathrm{h}$ \\
\hline Wind Speed & $V v$ & $0 \mathrm{Km} / \mathrm{h}$ \\
\hline $\begin{array}{l}\text { Equivalent Mass of the } \\
\text { Rotating Components }\end{array}$ & $m_{v}^{\prime}$ & $3 \% \cdot m \mathrm{~kg}$ \\
\hline $\begin{array}{l}\text { Efficiency of the } \\
\text { Transmission }\end{array}$ & $\eta_{t}$ & $\begin{array}{c}1 \\
\text { (dimensionless) }\end{array}$ \\
\hline Drivetrain & $i_{g}$ & 1 \\
\hline $\begin{array}{l}\text { Dynamic Radius of the } \\
\text { Wheel / Tire }\end{array}$ & $r d$ & $0.2 \mathrm{~m}$ \\
\hline
\end{tabular}

Chart 6. Parameters for the vehicle

The results achieved have been based on technical data from the manufacturers of their respective equipment. Four manufacturers of electric motors in three possible configurations for the drivetrain system have been analyzed, as well as six manufacturers of AC drivesaccording to their respective configuration- and also two technologies of power supply source: lead-acid (automotive, stationary and tractive) and lithium-ion to be compared referring to the storage of energy.

Based on the theoretical mathematical pattern of the longitudinal dynamics of the vehicle, it has been possible to determine the necessary parameters, such as power, traction torque and speed for vehicle performance.

It has been sought, commercially, common use equipment for the industry that could be able to meet the demands of the project. In addition to the technical features of the components, we have analyzed aspects such as weight that the components may add to the vehicle and their economic feasibility, and thus defined the components to be used. The technical and economic data from the Smart Fortwo powertrain vehicle was used for comparison purposes. It was compared to the data of the equipment defined for the project, regarding weight and economic feasibility.

The constructional characteristics of 6-pole electric motors present better results when inserted into the electric propulsion system for a vehicle. Despite all of them meet the power, torque and rotation conditions required to be applied to the traction system, some do not meet the criteria of maximum time of locked rotor, according to the traction configuration, as shown in Graph 1.

\footnotetext{
${ }^{4}$ On lead-acid batteries, the discharge regime specifications are given in 5,10 and 20 hours, which is equivalent to the discharges rates of $0,2,0,1$ e 0,05 of rated capacity. EVs, generally, use a discharge rate of 0,2 .
} 


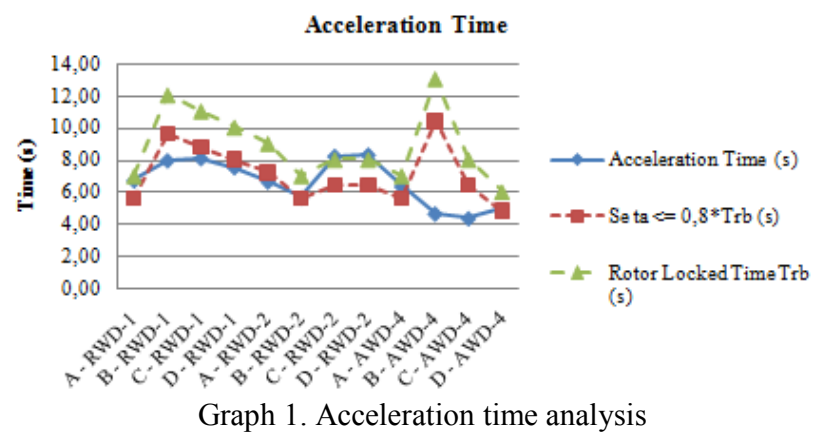

The best propulsion characteristics were presented by the motors B, C and D - in both RWD-1 and AWD-4 configurations - and by the motors $\mathrm{A}$ and $\mathrm{B}$ in RWD-2 configuration. They have presented time of acceleration shorter than $80 \%$ of maximum time of locked rotor.

Graphs 2, 3, 4 and 5 present comparisons between the economic feasibility and weight of the EV, considering the weighted value of 1 for the powertrain of the vehicle.

Graphs 2, 3, 4 and 5 still explore the weight comparison that may be added to the vehicle's body according to the model of the traction configuration. The maximum, average and minimum values for each configuration are mentioned, as well as the comparison between lead-acid and lithium-ion energy storage technologies.
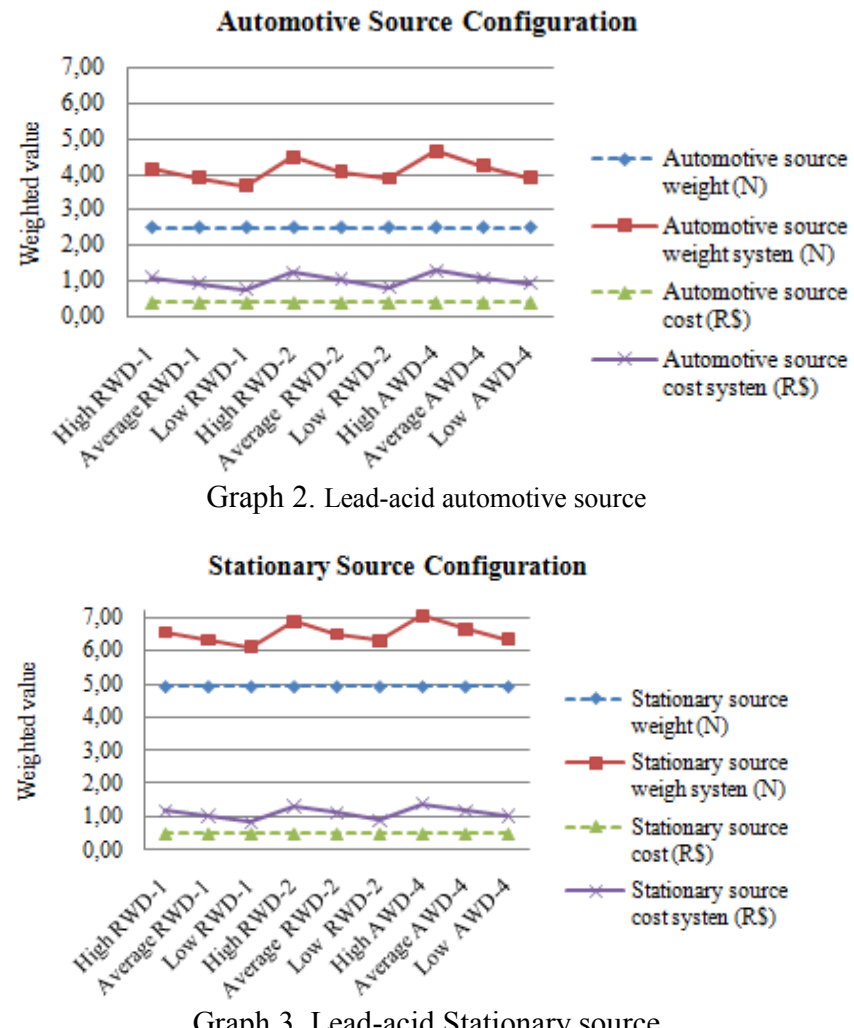

Graph 3. Lead-acid Stationary source
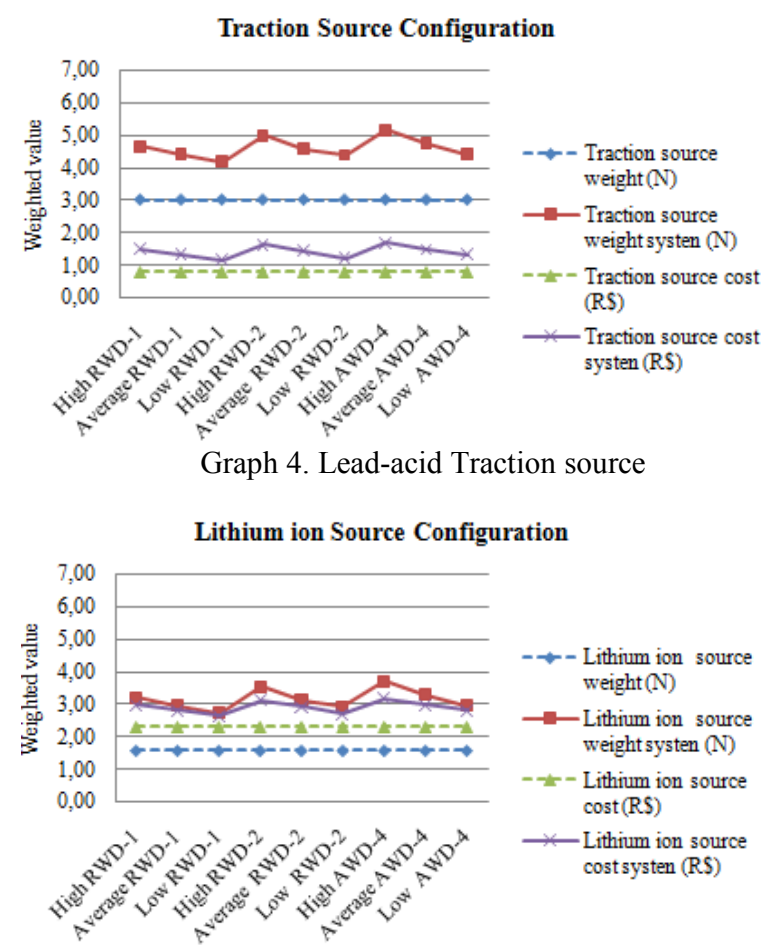

Graph 5. Lithium-ion Source

The comparisons of the Graphs 2, 3, 4 and 5 clearly demonstrate that the energy source which adds the most weight to the body of the vehicle is the lead-acid stationary source. It is able to multiply the vehicle's body weight seven times, compared to ICE propulsion system. In general, the energy source is the element which most adds weight to the vehicle.

The electric propulsion system economic viability may have a lower cost compared to ICE system, according to the cost divergence between the lead-acid sources and the lithium-ion ones in the RWD-1, RWD-2 and AWD-4 configurations.

However, in the RWD-1 configuration with one electric motor for propulsion, it makes necessary the use of a mechanical drive system for speed compensation in curves, turning the system into a non-compact form, which may present an impact on the costs and weight of the project.

One-drive systems, such as RWD-2 and AWD-4, are more compact because they do not require a mechanical drive system. Nevertheless, they not only add the highest weight, but also the manufacturing cost to the vehicle. One-drive systems still need a programmable logic control system (PLC) for the speed compensation of the wheels. The PLC controls the speed of the rotors on maneuvers through a software, which it may generate higher costs to the project.

The economic viability with the electric propulsion system may present lower costs compared to the ICE system, considering the weighted value of 1 for the powertrain of the ICE vehicle, as presented in Graphs 2 and 3. It takes places through the costs of the automotive and stationary lead-acid power source in RWD-1, RWD2 and AWD-4 configurations.

Through the analysis of the technical parameters of the equipment, the weight added to the body and the economic viability, the best alternative for the development of the propulsion subsystem has been 
found, among the proposed alternatives. The appropriate alternative for the project is presented in Graph 6, through equation 5.3 .

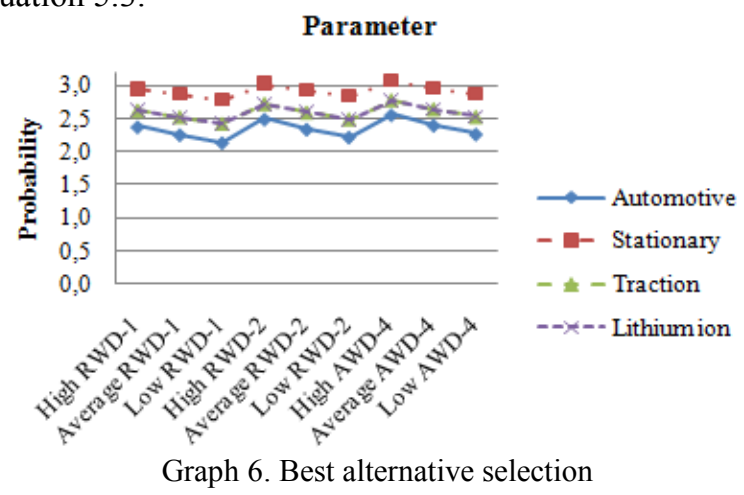

Therefore, the recommended configuration would be the RWD-2 with automotive lead-acid power source, because its costs and added weight are inferior compared to the other configurations, presenting a compact system with better cost-benefit ratio for the project

For the configuration RWD-2, defined in Graph 6 according to equation 5.3, the best alternative among the AC drives is the model F presented in Graph 7, considering the parameters of rated output current, costs, weight and dimensions.

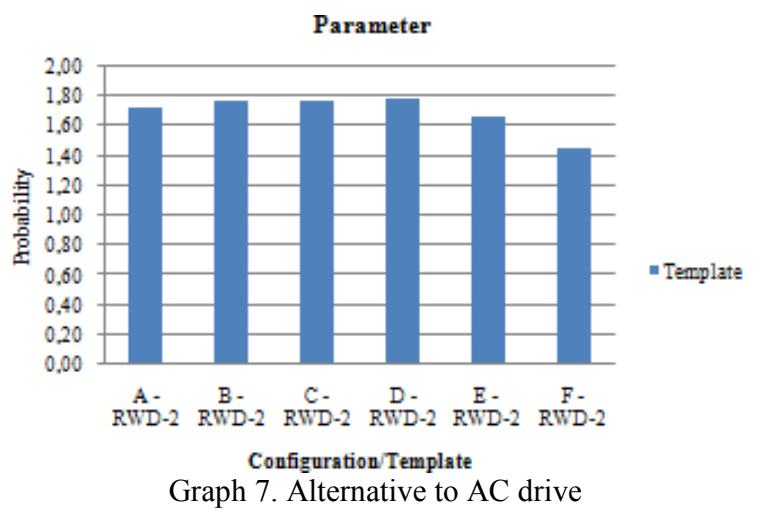

\section{Conclusion}

It can be concluded that, through the axiomatic research method, an alternative model for the elaboration of an electric propulsion system through common large scale industrial equipment can be developed.

Through the dynamic characteristics for the vehicle and the manufacture of large-scale electrical equipment, the main equipment for the traction system have been identified as; the electric motor, controller / the AC Drive and the power supply model for energy storage, as well as three alternatives for the propulsion configuration have been elaborated.

According to Graph 6, it can be concluded that the RWD-2 configuration can be elaborated using either the A or B motors besides an automotive lead-acid power source and also be controlled by the AC drive model F. This configuration has the best attractive characteristics to be implemented in the traction system of an urban electric vehicle, despite the weight added to the vehicle's body. It presents lower implementation costs compared to the internal combustion engine propulsion system.

With the results obtained through the theoretical equation and the technical data from the equipment for the project, it is understood that the goals for a subsystem of propulsion with popular characteristics using industrial equipment in a large scale can be met. It can still be concluded that the efforts on research for energy sources must be kept in order to provide sources with low cost, lower weight and higher energy capacity.

\section{References}

[1] HORI, Y.; FUJIMOTO, H.; MAEDA, K. Four-wheel Drivingforce Distribution Method for Instantaneous or Split Slippery Roads for Electric Vehicle. Advanced Motion Control (AMC), 12th IEEE International Workshop on, Kashiwa Japan, 2012.

[2] EHSANI, M.; GAO, Y.; GAY, S. E.; EMADI, A. Modern Electric, Hybrid Electric, and Fuel Cell Vehicles. New York: CRC PRESS, 2005.

[3] GILlESPIE, T. D. Fundamentals of Vehicle Dynamics. SAE Society of Automotive Engineers, 1992

[4] LARMINIE, J.; LOWRY, J. Electric Vehicle Technology Explained. Wiley: Osford, 2003.

[5] SOCIETY OF AUTOMOTIVE ENGINEERS. SAE J1263: road load measurement and dynamometer simulation using coastdown techniques. Warrendale, revised mar. 2010.

[6] ARRABACA, D. A.; GIMENES, S. P. Eletrônica de potência: conversores de energia. 1. ed. São Paulo: Érica, 2011.

[7] WEG Indústrias S/A. Guia de aplicação de inversores de frequência. Mundo Elétrico 2004.

[8] DEL TORO, V. Fundamentos de máquinas elétricas. Rio de Janeiro: Prentice-Hall, 1994.

[9] WEG Indústrias S/A. Motores elétricos: Guia de Especificações. 2015

[10] VOGES. Motores elétricos trifásicos. Guia de Especificações 2010.

[11] NOVA - motores e geradores. Motores Trifásicos. 2015.

[12] SIEMENS. Motores elétricos de baixa tensão. Guia de Especificações. 2010.

[13] CHAGAS, M. W. P. Novas tecnologias para avaliação de baterias. 2007. 97 f. Dissertação - Instituto de Engenharia do Paraná (LACTEC), Curitiba, 2007.

[14] JOHNSON Controls. Treinamento técnico em baterias automotivas. Manual do Automóvel. Sorocaba, 2009.

[15] IEEE Recommended Practice for Design Features Lead-Acid Batteries for Stationary Applications. IEEE Std 485-2010, p. 190, April 2011.

[16] CROSS, N. Engineering design methods. 4. ed. England: WILEI, 2000

[17] SOZO, V. Utilização da abordagem axiomática no processo de tomada de decisões pertinentes ao projeto conceitual de produtos. 2002. 120 f. (UFSC), Florianópolis, 2002.

[18] SISL - Sustainable Innovative Solutions Limited. Creating a sustainable competitive advantage with continuous systematic customer-driven innovation. For Innovation 2008 